\title{
From Website to Moodle in a Blended Learning Context
}

Lillian Buus, Department of Communication and Psychology, Aalborg University, Aalborg, Denmark

\begin{abstract}
This paper presents findings collected from a collaborative implementation project established in Spring 2008 between Aalborg University's IT-department in the Faculty of Social Science (FSS) and the E-Learning Cooperation Unit (ELSA) with the view to implement Moodle in FSS. The purpose of this cooperation was conceived from an organisational desire to establish a virtual learning environment (VLE), where it was possible, to build activities and underpin the pedagogical approach. Another perspective was to further improve the communication between the administration, teachers and students. This paper will highlight the development process and some of the didactic considerations undertaken for the implementation. The evaluations undertaken during the process will also be presented, along with the results collected in the use of Moodle to highlight the educational changes.
\end{abstract}

\section{KEYWORDS}

Blended Learning, Learning Activities, Learning Practice, Moodle Platform, Problem Based Learning, Virtual Learning Environments

\section{INTRODUCTION}

Back in 2008 interest was evolving at the Faculty of Social Science (FSS) at Aalborg University (AAU) on how to provide a more collaborative experience for students and also provide teachers with the opportunity to introduce different degrees of interaction in their teaching by using a learning management system (LMS). This was the starting point for implementation of the learning management system (LMS) named Moodle ${ }^{1}$ at FSS. Following the teachers expression of interest to have the possibility to integrate more interaction among students into the lectures; such interaction among the students being in the form of dialogue and collaboration building on activities posted in the virtual learning environment (VLE) (wiki, glossary, forums, etc.), and also collaboration between the students in a more general manner (Lone Dirckinck-Holmfeld, 2002; Lone Dirckinck-Holmfeld $\&$ Buus, 2003). This interaction would also underpin the pedagogical approach at AAU - Problem Oriented and Problem Based Learning ((PO)PBL) (Barge, 2010; Lone Dirckinck-Holmfeld, 2002; Kolmos, 2009, 2009). At the same time, the University's management stipulated as their objectives for 2009-2011 "Developing problem based learning in relation to ICT and e-learning in relation to inter-disciplinary activities (Gylstorff et al., 2009, p. 1).

For the project pilot, it was decided to start with a small study program, which was comprised of a total of 17 students, one secretary and only a couple of teachers. FSS had already introduced educational practice and experiences from another $\mathrm{LMS}^{2}$ and the pilot program initially worked on transforming and implementing their approach to blended learning into the Moodle environment taking into consideration the differences in the two programs. The faculty asked the E-learning Cooperative Unit (ELSA) to be involved in the pilot project. Thus on this small scale the study program was 
implementing Moodle as the e-learning platform and they tried out some of the features Moodle offered during the period of one course $e^{3}$.

Following the initial pilot project FSS asked ELSA to continue by designing and developing a structure for the implementation of Moodle for their $1^{\text {st }}$ and $2^{\text {nd }}$ semester study program (Entry Term) with potentially 900 students. This project should also contain a plan for teacher training in the use of and possibilities in Moodle together with training for secretaries for their work in the VLE. Furthermore this should be the foundation for implementing Moodle throughout all of FSS. Students then would become familiar with the VLE upon entering the university and have it as a common platform throughout their studies for activities, material and communication on course matters.

From a research perspective this therefore became a project dealing with perspectives on: "How can we design and accomplish an implementation process for implementing a VLE at the Faculty of Social Science?" The design needs to take into account the pedagogical approach at AAU, where the pedagogical approach are dealing with problem-based learning (PBL) (Barge, 2010; Busk Kofoed \& Hansen, 2004; Kolmos \& Graaff, 2003). Furthermore the implementation of the VLE must provide a better opportunity for collaboration and sharing both between teachers and students but also among students in general, and taking into account the possibility to use a blended learning approach and build more on online activities (Savin-Baden, 2008; Savin-Baden \& Wilkie, 2006; Walker, 2014; Weller, 2007).

\section{THE IDEAS AND OBJECTIVES OF THE PROJECT}

This project to develop and design the structure at the Entry term was initially based on their current structure of education and the way in which they (secretaries and teachers) were using ordinary websites to communicate and inform, but also to share learning objectives, content and material for students. Using this as the fundamental knowledge in the design and bearing in mind the pedagogical approach at AAU, the team of instructional designers and developers tried to develop a structure for the virtual learning environment to support this. An aim was furthermore to integrate features in the e-learning platform focusing on supporting the students in their learning and create a virtual learning environment where they could collaborate.

The instructional designer took an action research approach concerning the design for learning activities (Lewin, 1946; Coghlan, 2005; Nielsen \& Svensson, 2006; Duus, Husted, Kildedal, Laursen, $\&$ Tofteng, 2012; Reason \& Bradbury, 2008). The action research approach was based on close collaboration between the participants (staff), the developers and the researchers. It was important to involve the participants and share knowledge and decisions with them during the process, to give ownership in the development and implementation process.

Another important focus in the development of the design was to support the program secretaries and teachers in their study-related work, and give them the possibility to interact with the student via the e-learning platform. The expectation from the institutional perspective was that the establishment of a virtual learning environment in Moodle would provide better opportunities for students to collaborate and share knowledge across modules and classes, supplemented by the possibility of a better dialogue between the people responsible for the educational program, and the teachers and students.

Staff and teachers at the Entry term program at FSS were not accustomed in the use of e-learning systems, but based their online information flow to students by using websites. This meant that it was primarily the secretaries of education who were responsible for posting information, as they were the ones who had access to the website. Teachers only had the possibility to post information either by asking the secretary to do so on their behalf or by establishing their own website for their course. This was likely to be changed when integrating Moodle. Part of the implementation plan was to make the management and staff aware of what could be part of the official website for external information, and what kind of information should be placed in Moodle for internal information and communication. 
12 more pages are available in the full version of this document, which may be purchased using the "Add to Cart" button on the product's webpage:

www.igi-global.com/article/from-website-to-moodle-in-ablended-learning-context/145216?camid=4v1

\section{Related Content}

An Intelligent Knowledge Treasure for Military Decision Support

Sanju Mishra and Sarika Jain (2019). International Journal of Web-Based Learning and Teaching Technologies (pp. 55-75).

www.igi-global.com/article/an-intelligent-knowledge-treasure-for-militarydecision-support/234287?camid=4v1a

Too Many Words, Too Little Support: Vocabulary Instruction in Online Earth Science Courses

Mary F. Rice and Donald D. Deshler (2018). International Journal of Web-Based Learning and Teaching Technologies (pp. 46-61).

www.igi-global.com/article/too-many-words-too-little-

support/198376?camid=4v1a

Framing Pedagogy, Diminishing Technology: Teachers Experience of Online Learning Software

Julia Thornton (2010). Web-Based Education: Concepts, Methodologies, Tools and Applications (pp. 1211-1231).

www.igi-global.com/chapter/framing-pedagogy-diminishing-

technology/41408?camid=4v1a

Research on Small Group Writing Activities Compared to Individual Flipped Model Through WhatsApp: Writing Skill

Yudhi Arifani (2022). International Journal of Web-Based Learning and Teaching

Technologies (pp. 1-10).

www.igi-global.com/article/research-on-small-group-writing-activities-

compared-to-individual-flipped-model-through-

whatsapp/281724?camid=4v1a 